\title{
Business Groups, Financing Constraints, and Investment: The case of India
}

\author{
Shubashis Gangopadhyay ${ }^{*}$, Robert Lensink ${ }^{* *}$, and Remco van der Molen ${ }^{* *}$
}

\author{
SOM Theme E Financial markets and institutions
}

\begin{abstract}
We examine the effect of business group affiliation on corporate investment behavior in India. We use a data set containing 684 Indian listed companies for the 1989-1997 period. We estimate a simple investment equation and find evidence that cash flow has a positive effect on investment spending of stand-alone firms, whereas for group affiliates cash flow is either insignificant or has a much lower coefficient. This suggests that business group affiliates have better access to external funds than stand-alone firms.
\end{abstract}

Keywords: business groups, investment, capital constraints, India.

(also downloadable) in electronic version: http://som.rug.nl/

\footnotetext{
*Indian Statistical Institute, Delhi Centre, and SERFA, India.

${ }^{* *}$ University of Groningen, PO Box 800, 9700 AV Groningen, the Netherlands.

Corresponding author: Robert Lensink, b.w.lensink@eco.rug.nl
} 


\section{Introduction}

Business groups form an important part of the Indian private sector; in 1993, group affiliated firms accounted for more than $80 \%$ of the private sector's assets, profits and sales (Khanna, 1997). Indian business groups are typically very diversified collections of legally independent firms that usually have a large proportion of family ownership. They contain up to more than 80 firms, which are typically clustered in several industries. Their origin often dates back to the colonial "managing agency" system, where the managing agency controlled large numbers of companies across a range of industries. The companies affiliated to a business group are often linked through cross-holdings of equity and interlocking directorates, and usually emphasize a common identity.

Why is the business group such a widespread phenomenon? One possible explanation is that in the presence of severe market imperfections, a business group may be a second-best efficient organizational form (Ghemawat and Khanna, 1998). Their scale and scope allow business groups to replicate functions that are performed by (financial) institutions in developed countries. Therefore, with ill-functioning capital markets, business groups may play an important role in generating and allocating funds to investment projects, two of the main functions of the capital market. With respect to corporate investment, this may imply that business group affiliates may have better access to external capital, either from within the group or from outside the group.

In a developing country like India, informational imperfections abound, preventing the capital market from functioning efficiently. Therefore, especially in developing countries, business groups may act as an intermediate between firms and markets.

From a theoretical perspective, business group affiliation may enhance a firm's access to external capital in two ways. The first way to improve access to external capital is that banks may be more willing to lend to a business group affiliate. One of the main characteristics of business groups is the existence of financial relationships between affiliated firms. These relationships take the form of cross-holdings of equity, interfirm loans, or mutual debt guarantees. These financial interlinkages may 
serve to mitigate moral hazard problems within the group (Berglöf and Perotti, 1994) or may be an effective means of risk sharing, because of the diversified nature of business groups. In markets rendered imperfect by asymmetric information, group membership can act as a signal of relative stability in cash flows, reducing the harmful affects of adverse selection (Gangopadhyay and Lensink, 2001). Together with the existence of debt-guarantees, it may reduce the probability of financial distress. Reputational effects are also likely to play a role; business group affiliation may serve as a quality sign, or familiarity with other firms of the same group may induce a creditor to be more willing to lend to a firm. Especially in a developing country like India, reputational effects may be of great importance, since the absence of a smoothly functioning and reliable legal system may make contract enforcement via a court very costly. ${ }^{1}$

Secondly, a firm may be able to obtain funding from other group companies. One can think of this in analogy to an internal capital market in a diversified firm. With respect to the efficient allocation of capital to productive uses, the business group structure may have informational advantages. Because the group superstructure, often consisting of the CEO's of the affiliated companies, has better access to firm specific information and may be more suited for enforcing the disclosure of information, it may do a better job in allocating funds than the capital market. However, the allocation of funds through intra-firm loans may be of limited size within a business group, because the affiliated firms are legally separate. To the extent that there does exist some internal allocation of funds, the business group may gain from its superior information. There is some empirical evidence that intra-group loans are substantial (Khanna and Yafeh, 1999). Moreover, as Ghemawat and Khanna (1998) argue, the informational problems are likely to be severe in India, whereas the agency problems may be partly relieved by the alignment of incentives through reciprocal equity holdings and family ownership. On average, the advantages of a business group's internal capital market may outweigh the inefficiencies through

${ }^{1}$ Although Indian law has a common-law origin, law enforcement is typically much more difficult than in the UK or the US (see La Porta et al. (1998)). For these reasons, banks may be more willing to lend to group affiliates. 
moral hazard problems. If business groups provide a relatively efficient allocation mechanism, this may also help the business group affiliates in generating external funds.

We hypothesize, therefore, that business group affiliates may have better access to external funds. Although there is some literature on Indian business groups and on the investment behavior of Indian firms (for references, see Section 2), our paper is to our knowledge the first to combine these two issues. ${ }^{2}$ We explicitly look at the effect of business group affiliation on investment spending in India.

We compare the investment behavior of business group affiliates with that of stand-alone companies and test the hypothesis that group affiliated firms are less capital constrained than stand-alone companies. We test for the presence of capital constraints by estimating the cash flow sensitivity of investment spending, taking the firm's cash flow as a proxy for internal funds. The data set we use contains 684 Indian listed companies, from 1989 to 1997 . Using a OLS fixed effects as well as a GMM-estimator to estimate a dynamic investment equation, we find evidence that cash flow has a positive effect on investment spending of stand-alone firms, whereas for group affiliates, cash flow is insignificant. This is in line with our hypothesis.

The rest of the paper is organized as follows. In section 2, we give an example of one of the business groups in India, the Tata group. Although business groups differ considerably in India, this example gives some insights into the organizational structure that is the main focus in our paper. Section 3 reviews the related literature. Section 4 describes the data and gives some descriptive statistics. In section 5, our estimation results are presented. In section 6 these results are discussed. Section 7 concludes.

\footnotetext{
${ }^{2}$ Khanna and Palepu (2000) may be an exception, but they used data for only one year, so that they are not able to estimate a real dynamic investment model. Bhandari, Dasgupta and Gangopadhyay (2000) also consider investment in group companies but their focus is on investment by financial institutions in group companies.
} 


\section{The Tata Group: an example}

The Tata Group is the largest and most distinguished business group in India. Starting in 1874 with a single textile mill, the group nowadays contains more than 80 firms in seven main business sectors (materials, engineering, energy, chemicals, consumer products, communications and information systems, and services). In 1995, it had sales of Rs. 220 billion and 270,000 employees and it has a leadership position in many industries. ${ }^{3}$

The founder of the Tata Group, Jamshedji Tata, already started to expand his industries to steel, hydroelectric power, modern manufacturing methods, and technical education and research. Tata Sons Ltd., which now is the principal investment holding company of the Tata Group, was the promoter of many new ventures in the first half of the twentieth century and continued to promote and manage all major Tata Group companies until 1970. After this, the managing agency system was abolished, and the group was no longer a legal construct.

A lot of interdependence remained, however, and Tata Sons still offers the Tata companies consultancy, management, and financial services. Tats Sons is also the proprietor of the Tata brand name, which is a registered trademark for a variety of product classes. The Tata brand name is one of the most valuable assets of the Tata Group. Tata Sons is not only the proprietor of this name, but is also responsible for promoting it at a central level. Companies that want to use this name have to subscribe to the Tata Brand Equity Scheme, implying the payment of a fee and the subscription to a code of conduct, ensuring high standards of quality and ethical business practices.

The Tata Sons Ltd. Board is made up of the chairpersons or CEOs of major operating Tata Group companies, and the elected chair of the Board of Tata Sons is recognized as the Group Chairman.

The main Tata companies are Tata Engineering and Locomotive Company (Telco), Tata Iron and Steel Company (Tisco), Tata Power, Associated Cement

\footnotetext{
${ }^{3}$ This section draws heavily on Khanna, Palepu and Wu (1998). Additional information has been obtained from the Tata Group.
} 
Company (ACC), Tata Chemicals, Tata Tea, and Indian Hotels. Together, these companies account for more than 80 percent of the Tata group's sales. The relative independence of these companies is illustrated by the fact that they diversified into new businesses, sometimes with little coordination. There exist cross-holdings of equity between these companies and Tata Sons. In 1996, Tata Sons held a minority stake in these companies varying from 3 to 13 percent; the Tata companies together owned almost 13 percent of Tata Sons. Moreover, there is a lot of activity between these and other Tata group companies. In some cases, this takes the form of intragroup loans, but more often firms invest in other group companies or new ventures. These companies are not only related through financial ties. Very often, they also have interlocking directorates, so that a relatively small group of managers and directors controls a large part of the group companies.

Many of the new ventures are set up by another important part of the Tata Group, Tata Industries Ltd. (TIL). This holding company, which was established in 1945, was the managing agency for the Tata Group until 1970. In 1983, following the preparation of a long-term strategic plan, Tata Industries pioneered the entry of the Tata Group into several new sectors (advanced electronics, biotechnology, advanced materials, and alternative energy). These sectors were expected to have a significant impact on India's economy in the future. Since then, Tata Industries has functioned as the catalyst for the introduction of new businesses within the Tata Group. These ventures were often partly financed by Tata Sons and the main Tata Group companies. TIL generally maintained a 10 to 20 percent stake in these new ventures.

Another way in which the Tata Group companies cooperate is in the recruitment of talented managers by Tata Administrative Services (TAS). New TAS officers are encouraged to rotate among the Tata companies, and to take advantage of the opportunity to work in several industries. The TAS program was set up in order to increase the mobility of managerial talent among group companies. 


\section{Related literature}

\section{Investment-cash flow sensitivity and business groups}

Since the seminal paper by Fazzari et al. (1988), a large literature has emerged on the relationship between internal funds and corporate investment. For an overview of this literature, see Lensink, Bo, and Sterken (2001). A general finding of this literature is the importance of internal funds as a determinant of investment spending. The higher the cost difference between internal and external funds, the more a firm will have to rely on its own funds.

Most of this literature concentrates on developed countries. However, the issues of financing constraints and access to capital markets are likely to be even more relevant in developing countries. Still, there are relatively few investment studies for developing countries.

Most of the literature takes the following approach. The sample is divided according to an a priori measure of financing constraints, after which the investmentcash flow sensitivities of the different subsamples are compared. One of the selection criteria which have been used, and which we will use in this paper, is business group affiliation. Hoshi et al. (1991) were the first to use business group affiliation as a selection criterion, comparing the investment of Japanese keiretsu firms with standalone companies. They estimate an investment equation by regressing investment on liquidity, Tobin's $q$, and lagged production, and find evidence that keiretsu firms, who typically have strong relationships with a main bank, are less sensitive to fluctuations in their internal funds than firms that do not have such a relationship. They interpret this as evidence that the keiretsu structure mitigates information problems, i.e., that keiretsu firms suffer less from market imperfections. Looking at Korean chaebols, Shin and Park (1999) find that chaebol firms' investment decisions are independent of internal funds, while investments of non-chaebol firms are significantly (positively) sensitive to internal funds. They also find evidence for the existence of internal capital markets in chaebols, which may explain why investment spending is independent of internal funds. This is interpreted as evidence that the asymmetric information problems between firms within the same chaebol are reduced. Shin and Park use liquidity, Tobin's $q$, and lagged sales growth as 
regressors. Their sample consists only of two years, 1994 and 1995, which leaves them only one observation per firm. Other examples of studies that compare the investment behavior of group members and stand-alone firms are Perotti and Gelfer (2001) on Russian financial industrial groups and Hermes and Lensink (1998) on Chilean Grupo's. The evidence they find is consistent with Hoshi et al. All studies find that for group affiliates, the effect of internal funds on investment is lower than for stand-alone firms.

So, despite the different countries and the differences in institutional structures, the outcomes of these studies are quite uniform. We can therefore conclude that there is some empirical evidence that asymmetric information problems are less detrimental to group affiliated firms, at least with respect to corporate investment.

\section{Investment studies on India}

We are not the first to estimate an investment equation for a panel of Indian firms. However, none of these studies consider the effect of business group affiliation on investment spending. ${ }^{4}$ Athey and Laumas (1994) use a sample of 256 firms from 1978 and 1986 to estimate the sensitivity of investment to internal funds in a simple sales accelerator model. They find that internal funds are relatively more important for large firms and firms that produce luxury goods. They explain the greater sensitivity of large firms' investment by Indian industrial policy, which stimulates small-scale enterprises. This preferential treatment makes small firms less financially constrained than large firms.

Athey and Reeser (2000) estimate a q-model of investment, using a sample of 142 firms from 1981 to 1986 . They divide their sample into three groups - small firms, large firms with limited access to capital markets, and large firms with easy access to capital markets. The latter group consists of firms that are very large or belong to of one of the top three business groups (Tata, Birla, and Mafatlal). They hypothesize that these firms will suffer less from asymmetric information problems. They find that internal funds are unimportant for small firms and the large firms with 
easy access to capital markets, whereas investment of large firms with limited access to capital markets is sensitive to internal funds.

Instead of using size a criterion for firm classification, Ganesh-Kumar et al. (2001) classify their sample of Indian firms according to outward orientation. They conjecture that export-oriented firms will face lower costs of external funds, and thus have lower investment-cash flow sensitivity. They argue that size is not a useful criterion in developing countries, because more assets only have a higher collateral value if the assets are marketable. This marketability may be problematic in developing countries. They use export orientation as a criterion, arguing that a higher export orientation means a greater ability to compete in world markets. In the new, liberalized Indian environment, the ability to compete in world markets may be an important determinant of investment project quality. Therefore, these firms may face lower costs of external funds. Using a GMM approach, they estimate an investment equation with lagged sales and cash flow as regressors. The authors find evidence that is consistent with their conjecture, i.e., investment spending of exporting firms is less sensitive to cash flow than that of domestic firms.

Eastwood and Kohli (1999) study the promotion of small-scale industry in India by directed bank lending. They find that large firms with new investment opportunities could obtain additional external finance, whereas small firms could not. This suggests that small firms were more financially constrained than large firms were. Moreover, the evidence suggests that the rise in bank lending has raised investment spending.

Recently, Khanna and Palepu (2000) have compared the performance of business group affiliates in India with that of stand-alone firms. They find that only above a certain degree of diversification, group diversification is beneficial to its members. Below this threshold, stand-alone firms perform better than group affiliates. They find evidence that group affiliated firms have disproportionately good access to international source of capital. These firms issue more global depository rights (GDRs) and are more closely followed by foreign financial analysts. Referring to the

${ }^{4}$ A notable exception is Bhandari Dasgupta and Gangopadhyay (2000) who, however, concentrate on the role of development financial institutions in the investment behavior of 
potential value creation of internal capital markets, they find no evidence that the role of internal capital markets differs between group affiliates and stand-alone companies. They find strong investment-cash flow sensitivities for all firms, and no difference between group affiliates and stand-alone firms. This suggests that the benefits of business group affiliation are in generating capital rather than in allocating it.

All in all, the literature suggests that there may be a positive relationship between group affiliation and a firm's ability to generate external funds. ${ }^{5}$ In this paper, we test whether this is true for the Indian case.

\section{Data description}

The variables are extracted from the CIMM database of the Center for Monitoring the Indian Economy (CMIE). We have yearly data for the 1989-1997 period. Constructing a balanced set resulted in a sample of 684 firms, of which 455 are group related and 229 are private. ${ }^{6}$ Since the dependent variable is net investment, derived by taking the first difference of net fixed assets, the first year of observations (1989) is not taken into account in the estimates. So, the basic data set contains 684 firms with 8 observations.

In tables 1 and 2, we give some descriptive statistics about our sample of firms. Panel A of table 1 shows that, on average, group affiliated firms are significantly larger than stand-alone firms. Moreover, group affiliates are older, have a lower debtto-assets ratio, and have higher sales. The performance of group affiliates, measured by their return on assets (ROA), appears to be slightly better then that of stand-alone companies. This result is probably not very robust, since we used only a crude

\footnotetext{
group and standalone companies.

${ }^{5}$ In contrast, the evidence on the allocation of capital through intra-group capital markets is much more fragmented and mixed. Conclusive evidence has been found neither for their existence nor for their efficiency. We leave this issue for further research.

${ }^{6}$ Some outliers were deleted from the sample. In total, we deleted 10 firms (6 private firms and 4 group-related firms).
} 
measure of ROA. Moreover, Khanna and Palepu (2000) find that the relationship between performance and group affiliation is non-linear.

The differences in firm size, age, and leverage warrants some further discussion, since differences in these variables may affect the degree to which a firm is capital constrained. ${ }^{7}$ Differences in cash-flow sensitivities between group affiliates and stand-alone firms may therefore be attributed to the underlying differences in size, age and leverage. We tried to get a clearer picture of the relationships between these variables by regressing group affiliation on firm size, age and leverage. ${ }^{8}$ From this we find that firm size is very significant, whereas the age of a firm is not significant once one controls for firm size.

Panel B gives some insights into the ownership structure of business group affiliates relative to that of stand-alone firms. The most remarkable difference is that a larger part of group affiliates' equity is held by other companies, whereas in standalone companies, the directors hold a larger stake.

Although a more detailed picture of equity ownership is needed, the results in table 1 are consistent with the anecdotal evidence about the importance of crossequity holdings in business groups. If we interpret both corporate ownership and directors' ownership as measures of insider ownership, the figures also suggest that insider ownership is not confined to business groups. Thus, expropriation of minority shareholders may be present in both group affiliates and stand-alone companies.

From table 2, we can see that there are some remarkable differences in the composition of corporate debt between group affiliates and stand-alone firms. Stand-

\footnotetext{
${ }^{7}$ We note, however, that both firm size and capital structure are endogenous variables with respect to firm investment and the degree of capital constraints. Simply because a firm suffers less from capital constraints, it may be bigger or have more leverage. Business group affiliation, in contrast, does seen to be rather constant over time. For our sample, all firms are either affiliated to a business group or not, and this stays constant during our sample period. Business group affiliation can thus be considered exogenous. Therefore, even if business group affiliation is highly correlated with firm size or capital structure, it may still be a worthwhile exercise to compare investment behavior of group affiliates and stand-alone firms.

${ }^{8}$ Note that we only run this regression in order to find out which variables are significantly related to group affiliation. The regression does not imply anything about causality. Regression results can be obtained on request.
} 
alone firms rely more on bank debt as a source of funding. This difference is highly significant both for the mean and for the median. We do not think that these figures are at odds with our hypothesis. Bank debt is only one form of external capital, and since group affiliates are typically larger than stand-alone firms, they may have better access to other sources of external funds, e.g. public debt. Moreover, the mere fact that a firm borrows more from a bank does not tell us anything about its access to external funds. To say anything about this, we would have to know more about the conditions of the loan.

We can also see from table 2 that group affiliates borrow more from companies that are affiliated to the same group. This difference is also significant in both panels. This provides some evidence for intra-group loans. However, we should note that intra-group loans make up only one percent of total borrowings, suggesting that the size of intra-group loans is limited. Group affiliates also borrow more from foreign investors. Again, this difference is significant, but very small. The overall evidence form table 2 is not very conclusive.

In order to estimate the cash flow sensitivity for our sample of firms, in the next section we present estimates of a simple investment equation. In the basic regressions, net investment scaled by the beginning-of-period total assets $(I / A)$ is explained by sales scaled by the beginning-of-period total assets $(S / A)$ and cash flow scaled by the beginning-of-period total assets $(C F / A)$. Table 3 gives some descriptive statistics of the variables for the total data set as well as for the sub-samples of group affiliates and stand-alone companies. From table 3, we see that the most remarkable difference between group related and stand-alone firms is the much higher standard deviation of net investment for stand-alone companies.

Table 4 gives a correlation matrix of the main variables for the different groups of firms. The most significant difference between the group related and the standalone firms concerns the correlation coefficient between cash flow and net investment. For group related firms this is much lower than for stand-alone firms. In the next section we will argue that the investment-cash-flow sensitivity may be used as a measure of financing constraints. The more a firm is financially constrained, the 
more will investment be sensitive to a measure of internal funds, such as cash flow. The much lower correlation coefficient between net investment and cash flow for group related firms might therefore be a first indication that group affiliates suffer less from financing constraints than stand-alone companies.

\section{Estimation Technique and Results}

We estimate a fairly standard accelerator cum cash-flow investment model, where cash flow is a measure of internal funds. The base equation we estimate reads as follows:

$$
I / A=\alpha_{1}+\beta_{1} S / A+\beta_{2}(C F / A) * D 1+\beta_{3}(C F / A) *(1-D 1)+\varepsilon
$$

where $I$ is net investment, measured as the change in net fixed assets, $A$ is beginningof-period total assets, $C F$ is cash flow and $\varepsilon$ is an error term. $D 1$ is a group affiliation dummy, taking value 1 if the firm is related to a business group, and 0 if it is a standalone firm. ${ }^{9}$

Cash flow is added to the model to examine the effects of capital market imperfections. The idea is that, in the case of financial constraints, investment will be sensitive to internal funds. By comparing the investment-cash flow sensitivity of different groups of firms (i.e., comparing $\beta_{2}$, for group affiliates, and $\beta_{3}$, for standalone firms) it is then possible to test which type of firm is more financially constrained (see, e.g. Fazzari et al. (1988)).

First, we estimate equation (1) using ordinary least squares. The equation is estimated in first differences (to account for fixed effects), and time dummies for the entire estimation period are taken into account. The result of this estimation is presented in table 5, column 1 . The sales coefficient has the expected sign and is significant. The cash flow coefficient appears to be insignificant for group affiliates, whereas it is significantly positive for stand-alone firms. This clearly suggests that

\footnotetext{
${ }^{9}$ We also estimated a model where we included lagged investment as an explanatory variable, but this did not change our results.
} 
stand-alone firms are more financially constrained then group firms, and is thus consistent with our hypothesis.

As we saw in section 3, group-firms are typically bigger and older than standalone firms are. One may argue that these differences between the two sub-samples drive our result. In order to correct for this possibility, we next distinguish firms by means of a size and an age indicator.

We estimate the following equations:

$$
\begin{aligned}
& I / A=\alpha_{1}+\beta_{1} S / A+\beta_{2}(C F / A) * D 2+\beta_{3}(C F / A) *(1-D 2)+\varepsilon \\
& I / A=\alpha_{1}+\beta_{1} S / A+\beta_{2}(C F / A) * D 3+\beta_{3}(C F / A) *(1-D 3)+\varepsilon
\end{aligned}
$$

where $\mathrm{D} 2$ is a dummy with value 1 if total assets of a firm is below the average total assets of all firms (2036.18), and 0 otherwise. D3 is a dummy with value 1 if the age of a firm is below the average age of all firms (below 34), and 0 otherwise. ${ }^{10}$

The results of these estimates are shown in columns 2 and 3 of table 5. Again, we find that sales has a significantly positive effect on investment. Furthermore, we find lower cash flow coefficients for smaller firms and for younger firms. Quite interestingly, this suggests that smaller and younger firms are less capital constrained than bigger and older firms. This finding is consistent with Athey and Laumas (1994), who find that small firms are less capital constrained than large firms.

However, we are not so much interested in the effect of size and age on investment-cash flow sensitivities per se, as we are in separating the effects of size and age from that of group affiliation. Therefore, we finally distinguish four groups, based on two indicators: the dummy for group affiliation on the one hand and the dummy for size or age on the other hand.

We estimate the following models:

$$
\begin{aligned}
I / A=\alpha_{1} & +\beta_{l} S / A+\beta_{2}(C F / A) * D 1 * D 2+\beta_{3}(C F / A) * D 1 *(1-D 2) \\
& +\beta_{4}(C F / A) *(1-D 1) * D 2+\beta_{5}(C F / A) *(1-D 1) *(1-D 2)+\varepsilon
\end{aligned}
$$

${ }^{10}$ In our OLS estimates, we also experimented with using the median values instead of values for the mean. This gave similar results. 


$$
\begin{aligned}
I / A= & \alpha_{1}+\beta_{1} S / A+\beta_{2}(C F / A) * D 1 * D 3+\beta_{3}(C F / A) * D 1 *(1-D 3) \\
& +\beta_{4}(C F / A) *(1-D 1) * D 3+\beta_{5}(C F / A) *(1-D 1) *(1-D 3)+\varepsilon
\end{aligned}
$$

The results of these estimations can be found in columns 4 and 5 of table 5 . From column 4, we can conclude that both small and large group-affiliates have lower cash flow sensitivities than their stand-alone counterparts. This is fully in line with our hypothesis. The same conclusion can be drawn from column 5 for older firms. These results are interesting and also confirm our hypothesis that group firms are less capital constrained than stand-alone firms. A puzzling result from column 5 is that for young, group-related firms the cash flow coefficient is even negative, whereas it is insignificant for young, stand-alone firms. ${ }^{11}$

Estimating our models using ordinary least squares might be problematic due to measurement and endogeneity problems. Therefore, we also estimate our models using an instrumental variable approach. The instrumental variable estimation technique controls for the fact that the explanatory variables are likely to be correlated with the error term and the firm-specific effect, and deals with possible endogeneity problems. More specifically, we estimate the investment models with the system generalized methods of moments (GMM) estimator, using a new version of DPD98 for Gauss (Arellano and Bond, 1998). For details about this technique we refer to the appendix.

The results of the GMM estimation are presented in table 6, where the five columns again refer to the five models that were presented above. The results for the accelerator effect are disappointing, since in all five models, the coefficient for sales is not significant at the $10 \%$ level. $^{12} \mathrm{We}$ interpret this as strong evidence for the endogeneity of sales.

${ }^{11}$ Perotti and Gelfer (2001) find a negative cash flow coefficient for firms in a centrally led group. They see this as evidence for the existence of large intra group capital markets. In our case, that would suggest that especially the younger firms in a group are financially interlinked. Since detailed data is lacking we are not able to derive firm conclusions on this issue.

${ }^{12}$ It appears that the significance of the sales coefficient depends very much on the exact set of instruments. 
From column 1, we can conclude that cash flow is insignificant for group affiliates, whereas it is positively significant for stand-alone firms; a conclusion that is in line with our hypothesis. The results of columns 2 and 3 are consistent with the OLS estimates, in that they suggest that younger and smaller firms have better access to external capital. The results reported in column 4 also confirm our OLS results. Group affiliation implies a lower cash flow coefficient, irrespective of firm size. In column 5, we find that this result also holds for younger firms, whereas older firms' cash flow coefficients are roughly the same for group affiliates and stand-alone companies. $^{13}$

In general, we can say that, although there is a large difference between the size of the coefficients from the OLS and GMM estimations, the basic message is similar: in most of the cases group affiliates are less financially constrained than stand-alone firms. ${ }^{14}$

\section{Discussion}

Although the above mentioned methodology has been followed by numerous researchers, it is not undisputed. To value our results it is important to have a closer look at these critiques. The main critique focuses on three issues; the (time independent) a priori classification of firms in different groups, the problem that internal funds may also proxy for the profitability of investment and the use of investment-cash flow sensitivity as a measure of financial constraints.

$\mathrm{Hu}$ and Schiantarelli (1998) criticize the a priori classification of firms. They point at three possible weaknesses of this approach. First, financing constraints are

${ }^{13}$ Significance levels of the cash flow variables were robust to different combinations of instruments.

${ }^{14}$ We also estimated our basic accelerator model for two different samples of firms, one for the stand-alone firms and one for the group firms. These results also confirm that group firms have better access to external capital than stand-alone firms. Results can be obtained on request. 
likely to be determined by a number of factors. A single indicator may not be able to distinguish between the effect of financing constraints and firm-specific effects. Second, the financing constraints may differ per year. This may especially be the case when the macroeconomic environment changes dramatically over time. Finally, the variable used to select firms may be correlated with the dependent variable, in which case the analysis suffers from selection bias. To address these weaknesses $\mathrm{Hu}$ and Schianterelli propose to estimate an endogenous switching model, where the premium on external finance is endogenously determined by a switching function.

We believe, however, that our classification is immune to this critique. First, we are not so much interested in finding all the factors that determine the financing constraints a firm faces Our primary interest is in the difference in financing constraints between stand-alone firms and group members. Second, business group affiliation does not seem to change a lot over time, at least not over the period in our sample. Third, business group affiliation seems to be a truly exogenous variable. We think this is the most important difference between using size or age as a classification criterion and classifying firms according to business group affiliation. As we saw in the description of the Tata Group, family ownership plays an important role in the composition of a business group. A large part of the firms is in the hands of a controlling family, and has been there for a long time. We also saw that a lot of the younger firms in the group started as new ventures, (partly) financed by older group members. These characteristics of business groups imply that business group affiliation is not based on firms' access to external capital.

And whereas it seems obvious that the size of a firm is partly determined by its investment, such a causal link from investment to group affiliation is less straightforward. Moreover, although in section 4 we saw that business group affiliation is correlated with firm size, the results reported in table 5 show that the effect of group affiliation on investment-cash flow sensitivity does not depend on firm size.

Some authors argue that the relationship between investment and measures for internal funds may suffer from the fact that internal funds may proxy for the profitability of investment. In that case, a positive relationship between internal funds 
and investment may be expected since firms with more liquidity are doing well and have better possibilities to invest ((Hoshi, et al., 1991). This may imply that the cash flow coefficient cannot be interpreted in terms of capital market imperfections. The usual way to get around this problem is to add Tobin's q as an independent variable. Although we agree with the possibility that the cash flow sensitivity may provide a weak indication of the existence of capital market imperfections, we have not added Tobin's $\mathrm{q}$ to the model. We have two reasons for this. First, the empirical measurement of $\mathrm{q}$ requires data on prices and numbers of stock outstanding. Concerning our sample, we are not able to come up with a proxy for q for many firms in our sample. So, if we would estimate a q-model, the sample would have been decreased considerably. Moreover, since data to construct $\mathrm{q}$ are in particular missing for stand-alone and thus smaller firms, estimating a q-model would probably create a selection bias. Second, it is well known that there are serious measurement problems with respect to q. Theoretically, a measure of marginal q is needed. However, since marginal $\mathrm{q}$ is not observable, average $\mathrm{q}$ is usually taken as a proxy. This probably introduces additional measurement problems. In our case, sales proxies for future profitability.

Kaplan and Zingales (1997) are the most prominent critics of the use of the investment-cash flow sensitivity as a measure of financial constraints. They argue that the sensitivity of investment to cash flow not necessarily increases monotonically as a firm is more financially constrained. In particular, they show that the investment-cash flow sensitivity as a measure of financing constraints breaks down for certain specifications of a firm's cost and production functions.

However, this critique only applies to situations where a higher investmentcash flow sensitivity is interpreted as a more severe financing constraint. Therefore, this critique only applies to part of our results. In many cases, however, we find evidence that cash flow is insignificant for group affiliates, whereas it is positively significant for stand-alone firms. In these cases, we are not comparing different investment-cash flow sensitivities, and so the critique does not hold. 


\section{Conclusions}

This paper studies the effect of business group affiliation on corporate investment behavior in India. Estimating a standard accelerator cum cash-flow investment model, we find evidence that cash flow has a positive and significant effect on investment spending of stand-alone firms, whereas for group affiliates the cash flow coefficient is much lower or insignificant. Taking account of measurement problems and endogeneity, we also estimate our model using a system GMM estimator. The results from this estimation are consistent with our OLS results. This suggests that business group affiliates have better access to external funds than stand-alone firms, a conclusion that is broadly consistent with our hypothesis.

The two sub-samples of group affiliates and stand-alone firms differ with respect to firm size, age and leverage. We also estimated our model while controlling for these differences. We find that after controlling for firm size, our first results continue to hold. After controlling for age, the results are less clear-cut, however. We do not consider this very problematic, since age is only weakly related with business group affiliation. We interpret our findings as an indication that business group affiliates in India have better access to external capital than stand-alone companies.

Note that our result does not say anything about the efficiency of the investments. Moreover, it would be interesting to find out if better access to external capital goes via other group companies or via external financial institutions. 


\section{Appendix: details of the system GMM estimation method}

The system GMM estimator combines the differenced equation with a levels equation to form a system GMM. Lagged levels are used as instruments for the contemporaneous differences and lagged differences as instruments for the contemporaneous levels. We adopt the system GMM estimation procedure since first difference GMM may suffer from weak instruments problems (Blundell and Bond (1998)). The coefficients we present, as well as the p-values, refer to two step GMM estimates, based on robust, finite sample corrected standard errors (Windmeijer, 2000). Note that the uncorrected two-step standard errors are severely biased for small samples. Therefore, most researchers present coefficients and standard errors based on one-step estimates. Windmeijer (2000) shows how the two step standard estimates can be corrected, and that is the approach we have followed. ${ }^{15}$ In all estimations we control for time effects by adding time dummies for 1990-1997. These time dummies are used as additional instruments.

The reliability of the system GMM estimation procedure depends very much on the validity of the instruments. We consider the validity of the instruments by presenting a Sargan test. The Sargan test is a test on overidentifying restrictions. It is asymptotically distributed as $\chi^{2}$ and tests the null hypothesis of validity of the (overidentifying) instruments. P-values report the probability of incorrectly rejecting the null hypothesis, so that a $\mathrm{P}$ value above 0.05 implies that the probability of incorrectly rejecting the null is above 0.05 . In this case, a higher P-value makes it more likely that the instruments are valid. We also test the reliability of the instruments of the level equation by presenting the Difference Sargan test. The Difference Sargan test is calculated by subtracting the value of the Sargan test of a first differenced GMM estimate form the value of the Sargan test of the system GMM estimate. The degrees of freedom of the Differenced Sargan test equals the degrees of freedom of the system GMM Sargan test minus the first differenced Sargan test. The Differenced Sargan test is also asymptotically distributed as $\chi^{2}$ and tests the null

\footnotetext{
${ }^{15}$ We thank Frank Windmeijer for providing the package of DPD98 including the corrected two step standard errors.
} 
hypothesis of validity of the (overidentifying) instruments in the level equation. So, the levels equations instruments are not rejected if the calculated value of the Differenced Sargan test is lower than the theoretical value of a $\chi^{2}$ variable with $n$ degrees of freedom.

The consistency of the estimates also depends on the absence of serial correlation in the error terms. This will be the case if the differenced residuals display significant negative first order serial correlation and no second order serial correlation. We present tests for first-order and second-order serial correlation related to the estimated residuals in first differences. The test statistics are asymptotically distributed as standard normal variables. The null hypothesis here relates to "insignificance" so that a low P-value for the test on first-order serial correlation and a high P-value for the test on second-order serial correlation suggests that the disturbances are not serially correlated. The serial correlation tests (M1 and M2 in the table) refer to the one-step GMM estimates.

We also present Wald tests. These test statistics are also asymptotically distributed as $\chi^{2}$ variables. The Wald test tests for joint significance of all, or a subset of parameters. The null hypothesis refers to "insignificance", implying that low Pvalues suggest joint significance. 


\section{References}

Arrellano, M and S. Bond (1998). Dynamic panel data estimation using DPD98 for Gauss: a Guide for users. Oxford University.

Athey, M.J. and P.S. Laumas (1994). Internal funds and corporate investment in India. Journal of Development Economics, 45, 287-303.

Athey, M.J. and W.D. Reeser (2000). Asymmetric information, industrial policy, and corporate investment in India. Oxford Bulletin of Economics and Statistics, 62, 2, 267-292.

Bhandari, L., Sudipto Dasgupta and Shubhashis Gangopadhyay (2000). Development Financial Institutions, Financial Constraints, and Growth: Evidence from the Indian Corporate Sector, mimeo.

Blundell, R. and S. Bond (1998). Initial conditions and moment restrictions in dynamic panel data models. Journal of Econometrics, 87, 115-143.

Eastwood, R and R. Kohli (1999). Directed credit and investment in small-scale industry in India: Evidence from firm-level data 1965-78. Journal of Development Studies, 35, 4, 42-63.

Fazzari, S.M., R.G. Hubbard and B.C. Petersen (1998). Investment, financing decisions, and tax policy. Brooking Papers on Economic Activity, 141-195.

Ganesh-Kumar A., K. Sen and R. R. Vaidya (2001). Outward orientation, investment and finance constraints: A study of Indian firms. Journal of Development Studies, 37, 4, 133-149.

Ghemawat, P. and T. Khanna (1998). The nature of diversified business groups: a research design and two cases. Journal of Industrial Economics, 46, 1, 35-61. 
Harris, J.R., F. Schiantarelli and M.G. Siregar (1994). The effect of financial liberalization on the capital structure and investment decisuions of Indonesian manufacturing establishments. World Bank Economic Review, 8, 17-47.

Hermes, N. and R. Lensink (1998). Regulatory change and the allocation of finance: the role of business conglomerates in Chile, 1983-1992. In V. Murinde, J. Doukas and C. Wihlborg (eds.), Financial sector reform and privitization in transition economies. North Holland, 217-239.

Hoshi, T. A.K. Kashyap and D. Scharfstein (1991). Corporate structure, liquidity, and investment: evidence from Japanese industrial groups. Quarterly Journal of Economics, 106, 33-60.

$\mathrm{Hu}, \mathrm{X}$. and F. Schiantarelli (1998). Investment and capital market imperfections: a swithing regression approach using firm panel data. Thee Review of Economics and Statistics, 53, 193-225.

Kaplan, S.N. and L. Zingales (1997). Do investment-cash flow sensitivities provide useful measures of financing constraints? Quarterly Journal of Economics, 112, 169215.

Khanna, T. (1997). Modern India. Harvard Business School case 9-797-108.

Khanna, T. and K. Palepu (2000). Is group affiliation profitable in emerging markets? An analysis of diversified Indian business groups. Journal of Finance, 55, 2, 867-891.

Khanna, T., K. Palepu and D. Wu (1998). The House of Tata, 1995: The next generation, Harvard Business School case 9-978-037. 
La Porta, R., F. Lopez-de Silanes, A. Shleifer, and R.W. Vishny (1998). Law and Finance. Journal of Political Economy, 106, 6, 1113-1155.

Lensink, R. H. Bo and E. Sterken (2001). Investment, capital market imperfections and uncertainty: theory and empirical results. Cheltenham: Edward Elgar.

Perotti, E.C. and S. Gelfer (2001). Red barons or robber barons? Governence and investment in Russian financial-industrial groups. European Economic Review, 45, 1601-1617.

Shin, H. and Y.S. Park (1999). Financing constraints and internal capital markets: evidence from Korean 'chaebols'. Journal of Corporate Finance, 5, 169-191.

Siregar, M.G. (1995). Indonesia's financial liberalization: an empirical analysis of 1981-1988 panel data. Institute of Southeast Asian Studies.

Windmeijer, F. (2000). A finite sample correction for the variance of linear two-step GMM estimators. IFS Working Paper 00/19. London: The Institute for Fiscal Studies. 
Table 1: Descriptive statistics ${ }^{a, b}$

\begin{tabular}{llllll}
\hline & All firms & Group firms & Stand-alone & Difference & $\begin{array}{l}\text { T-stat. for } \\
\text { Difference }\end{array}$ \\
\hline \hline & & & & & \\
Panel A: summary statistics & & & & & \\
Total assets & 1884.79 & 2539.94 & 583.06 & 1956.88 & $11.26^{* * * \mathrm{c}}$ \\
Age & 33.95 & 35.29 & 31.28 & 4.00 & $6.58^{* * *}$ \\
Debt-assets ratio & 0.42 & 0.41 & 0.44 & -0.03 & $3.27^{* * *}$ \\
Sales & 1580.20 & 2134.18 & 479.50 & 1654.68 & $15.00^{* * *}$ \\
ROA & 0.05 & 0.05 & 0.04 & 0.01 & $2.31^{* *}$ \\
& & & & & \\
\hline
\end{tabular}

Panel B: ownership structure

$\begin{array}{llllll}\text { Foreign ownership } & 0.09 & 0.10 & 0.07 & 0.03 & 7.95 * * * \\ \begin{array}{l}\text { Domestic Institutional } \\ \text { ownership }\end{array} & 0.16 & 0.18 & 0.13 & 0.05 & 12.63 * * * \\ \text { Corporate ownership } & 0.31 & 0.35 & 0.24 & 0.10 & 18.87 * * * \\ \text { Directors' ownership } & 0.10 & 0.06 & 0.20 & -0.14 & 33.76 * * * \\ \text { Top 50 ownership } & 0.06 & 0.05 & 0.08 & -0.03 & 13.28 * * * \\ \text { Dispersed ownership } & 0.27 & 0.26 & 0.28 & -0.02 & 5.12 * * *\end{array}$

a $\quad$ Figures are averages for the 1989-1997 period.

b In panel A, total assets include fixed assets, investments, and current assets. Age is the number of years from incorporation. The debt-assets ratio measures the total borrowings of a company as a fraction of its total assets. Sales consist of the revenue generated from a firm's main business activity. The return on assets is measured as (profit after tax + dividends paid)/total assets.

The variables in panel B are defined as follows: foreign ownership is the ownership by foreign firms and financial institutions. Domestic institutional ownership measures the ownership stake of all state-run financial institutions. Corporate ownership measures the stake held by other companies, other than those mentioned above. Director's ownership is the stake owned by the directors and their relatives. Top 50 ownership measures the stake held by the 50 largest shareholders, other than those in the above categories. The rest of the shares is held by dispersed owners.

c $\quad * * *, * *, *$ denote significance at the $1 \%, 5 \%, 10 \%$-level, respectively. 
Table 2: composition of corporate debt ${ }^{\mathrm{a}, \mathrm{b}}$

Borrower type All firms Group firms Stand-alone firms t-stat. for difference

Panel A: means

$\begin{array}{lllll}\text { Bank } & 0.437 & 0.415 & 0.480 & 9.33^{* * * \mathrm{c}} \\ \text { Other financial institution } & 0.256 & 0.249 & 0.271 & 3.38^{* * *} \\ \text { Government } & 0.022 & 0.022 & 0.021 & 0.65 \\ \text { Group company } & 0.007 & 0.010 & 0.001 & 6.19^{* * *} \\ \text { Other company } & 0.027 & 0.028 & 0.024 & 2.14^{* *} \\ \text { Foreign } & 0.007 & 0.010 & 0.002 & 5.39 * * *\end{array}$

Panel B: medians

z-stat. for difference ${ }^{\mathrm{d}}$

$\begin{array}{lllll}\text { Bank } & 0.412 & 0.389 & 0.461 & 8.99 * * * \\ \text { Other financial institution } & 0.201 & 0.196 & 0.215 & 1.15 \\ \text { Government } & 0.000 & 0.000 & 0.000 & 2.48^{* *} \\ \text { Group company } & 0.000 & 0.000 & 0.000 & 3.53^{* * *} \\ \text { Other company } & 0.000 & 0.000 & 0.000 & 1.22 \\ \text { Foreign } & 0.000 & 0.000 & 0.000 & 1.94 *\end{array}$

a Figures are averages for the 1989-1997 period.

b This table compares components of corporate debt of group firms and stand-alone firms. The components are measured as the share of total borrowings obtained from a type of borrower. Bank debt includes both long- and short-term bank debt. Borrowings from the government include loans from central government, state governments and government owned development institutions. Group companies include holding companies, subsidiaries and group companies, i.e., companies under the same management. Thus, stand-alone firms are not excluded by definition. Loans from other companies represents loans from companies that are not included in group companies. Foreign borrowing refers to foreign institutions, not foreign currency. Panel A gives the mean share of total borrowings for a particular type of borrower, whereas Panel B gives the median shares.

$* * *, * *$ and $*$ denote significance at the 1,5 , and 10 percent level, respectively.

Denotes z-statistic for the outcome of a Wilcoxon signed-rank test. 
Table 3: Descriptive Statistics ${ }^{\text {a }}$

\begin{tabular}{|c|c|c|c|c|}
\hline & Mean & Std dev. & Min & Max \\
\hline \multicolumn{5}{|l|}{$I / A$} \\
\hline All firms & 0.091 & 0.301 & -0.726 & 13.182 \\
\hline Group affiliates & 0.089 & 0.200 & -0.488 & 3.509 \\
\hline Stand-alone & 0.094 & 0.437 & -0.726 & 13.181 \\
\hline \multicolumn{5}{|l|}{$S / A$} \\
\hline All firms & 1.462 & 1.017 & 0.000 & 20.619 \\
\hline Group affiliates & 1.464 & 1.110 & 0.000 & 20.619 \\
\hline Stand-alone & 1.457 & 0.804 & 0.000 & 8.545 \\
\hline \multicolumn{5}{|l|}{$C F / A$} \\
\hline All firms & 0.094 & 0.151 & -3.837 & 3.909 \\
\hline Group affiliates & 0.096 & 0.129 & -3.837 & 1.393 \\
\hline Stand-alone & 0.091 & 0.188 & -1.370 & 3.909 \\
\hline
\end{tabular}


Table 4: Correlation Matrix

\begin{tabular}{llll} 
All firms & & & \\
\hline \hline & $I / A$ & $S / A$ & $C F / A$ \\
$S / A$ & 1.00 & & \\
$C F / A$ & 0.09 & 1.00 & 1.00
\end{tabular}

Group firms

\begin{tabular}{llll}
\hline \hline & $I / A$ & $S / A$ & $C F / A$ \\
\hline$I / A$ & 1.00 & & \\
$S / A$ & 0.02 & 1.00 & 1.00
\end{tabular}

Stand-alone firms

\begin{tabular}{llll}
\hline \hline & $I / A$ & $S / A$ & $C F / A$ \\
\hline$I / A$ & 1.00 & & \\
$S / A$ & 0.22 & 1.00 & 1.00
\end{tabular}


Table 5: OLS estimates of effects of cash flow on investment ${ }^{a, b}$

\begin{tabular}{|c|c|c|c|c|c|}
\hline & 1 & 2 & 3 & 4 & 5 \\
\hline S/A & $\begin{array}{l}0.1529 \\
(0.000)\end{array}$ & $\begin{array}{l}0.1353 \\
(0.000)\end{array}$ & $\begin{array}{l}0.1501 \\
(0.000)\end{array}$ & $\begin{array}{l}0.1431 \\
(0.000)\end{array}$ & $\begin{array}{l}0.1522 \\
(0.000)\end{array}$ \\
\hline$(\mathrm{CF} / \mathrm{A}) * \mathrm{D} 1$ & $\begin{array}{l}-0.0333 \\
(0.501)\end{array}$ & & & & \\
\hline$(\mathrm{CF} / \mathrm{A}) *(1-\mathrm{D} 1)$ & $\begin{array}{l}0.3321 \\
(0.000)\end{array}$ & & & & \\
\hline$(\mathrm{CF} / \mathrm{A}) * \mathrm{D} 2$ & & $\begin{array}{l}0.0995 \\
(0.009)\end{array}$ & & & \\
\hline$(\mathrm{CF} / \mathrm{A})^{*}(1-\mathrm{D} 2)$ & & $\begin{array}{l}1.5927 \\
(0.000)\end{array}$ & & & \\
\hline$(\mathrm{CF} / \mathrm{A}) * \mathrm{D} 1 * \mathrm{D} 2$ & & & & $\begin{array}{l}-0.0560 \\
(0.251)\end{array}$ & \\
\hline$(\mathrm{CF} / \mathrm{A}) * \mathrm{D} 1 *(1-\mathrm{D} 2)$ & & & & $\begin{array}{l}1.1387 \\
(0.000)\end{array}$ & \\
\hline$(\mathrm{CF} / \mathrm{A}) *(1-\mathrm{D} 1) * \mathrm{D} 2$ & & & & $\begin{array}{l}0.3281 \\
(0.000)\end{array}$ & \\
\hline$(\mathrm{CF} / \mathrm{A}) *(1-\mathrm{D} 1) *(1-\mathrm{D} 2)$ & & & & $\begin{array}{l}4.6988 \\
(0.000)\end{array}$ & \\
\hline$(\mathrm{CF} / \mathrm{A}) * \mathrm{D} 3$ & & & $\begin{array}{l}-0.0517 \\
(0.283)\end{array}$ & & \\
\hline$(\mathrm{CF} / \mathrm{A}) *(1-\mathrm{D} 3)$ & & & $\begin{array}{l}0.3660 \\
(0.000)\end{array}$ & & \\
\hline$(\mathrm{CF} / \mathrm{A}) * \mathrm{D} 1 * \mathrm{D} 3$ & & & & & $\begin{array}{l}-0.094 \\
(0.076)\end{array}$ \\
\hline$(\mathrm{CF} / \mathrm{A}) * \mathrm{D} 1 *(1-\mathrm{D} 3)$ & & & & & $\begin{array}{l}0.2505 \\
(0.017)\end{array}$ \\
\hline$(\mathrm{CF} / \mathrm{A}) *(1-\mathrm{D} 1) * \mathrm{D} 3$ & & & & & $\begin{array}{l}0.1233 \\
(0.231)\end{array}$ \\
\hline$(\mathrm{CF} / \mathrm{A}) *(1-\mathrm{D} 1) *(1-\mathrm{D} 3)$ & & & & & $\begin{array}{l}0.4127 \\
(0.000)\end{array}$ \\
\hline $\mathrm{N}$ & 4788 & 4788 & 4788 & 4788 & 4788 \\
\hline RSS & 587.50 & 578.82 & 585.87 & 568.04 & 585.02 \\
\hline TSS & 639.19 & 639.19 & 639.19 & 639.19 & 639.19 \\
\hline
\end{tabular}




$\begin{array}{llllll}\text { WALDJS }^{\mathrm{c}} & 368.53 & 409.00 & 375.16 & 501.79 & 385.22 \\ & (0.000) & (0.000) & (0.000) & (0.000) & (0.000) \\ \text { WALDTM }^{\mathrm{d}} & 38.96 & 10.884 & 29.34 & 12.29 & 31.73 \\ & (0.000) & (0.144) & (0.000) & (0.091) & (0.000)\end{array}$

a All variables are scaled by beginning-of-period total assets, A. Dependent variable is investment, measured as the change in gross fixed assets. Independent variables are sales, S, and cash flow, CF. The dummy variables D1, D2, and D3 refer to group affiliation (1 if affiliated, 0 if not), size (1 if small, 0 if large), and age (1 if young, 0 if old), respectively.

b P-values are in parentheses.

c WALDJS gives the test statistic for a Wald test of joint significance of the independent variables; p-values are in parentheses.

d WALDTM gives the test statistic for a Wald test of the significance of the time dummies (coefficients are not reported); $\mathrm{p}$-values are in parentheses. 
Table 6: System GMM estimates of effects of cash flow on investment ${ }^{a, b, c}$

\begin{tabular}{|c|c|c|c|c|c|}
\hline & 1 & 2 & 3 & $4^{d}$ & $5^{d}$ \\
\hline S/A & $\begin{array}{l}0.098 \\
(0.111)\end{array}$ & $\begin{array}{l}-0.1982 \\
(0.114)\end{array}$ & $\begin{array}{l}0.1093 \\
(0.613)\end{array}$ & $\begin{array}{l}0.1473 \\
(0.262)\end{array}$ & $\begin{array}{l}0.0424 \\
(0.566)\end{array}$ \\
\hline$(\mathrm{CF} / \mathrm{A}) * \mathrm{D} 1$ & $\begin{array}{l}-0.0014 \\
(0.995)\end{array}$ & & & & \\
\hline$(\mathrm{CF} / \mathrm{A}) *(1-\mathrm{D} 1)$ & $\begin{array}{l}1.8778 \\
(0.022)\end{array}$ & & & & \\
\hline$(\mathrm{CF} / \mathrm{A}) * \mathrm{D} 2$ & & $\begin{array}{l}1.0600 \\
(0.157)\end{array}$ & & & \\
\hline$(\mathrm{CF} / \mathrm{A}) *(1-\mathrm{D} 2)$ & & $\begin{array}{l}1.0556 \\
(0.019)\end{array}$ & & & \\
\hline$(\mathrm{CF} / \mathrm{A}) * \mathrm{D} 1 * \mathrm{D} 2$ & & & & $\begin{array}{l}0.3042 \\
(0.523)\end{array}$ & \\
\hline$(\mathrm{CF} / \mathrm{A}) * \mathrm{D} 1 *(1-\mathrm{D} 2)$ & & & & $\begin{array}{l}1.1775 \\
(0.002)\end{array}$ & \\
\hline$(\mathrm{CF} / \mathrm{A}) *(1-\mathrm{D} 1) * \mathrm{D} 2$ & & & & $\begin{array}{l}2.0930 \\
(0.009)\end{array}$ & \\
\hline$(\mathrm{CF} / \mathrm{A}) *(1-\mathrm{D} 1) *(1-\mathrm{D} 2)$ & & & & $\begin{array}{l}1.6976 \\
(0.002)\end{array}$ & \\
\hline$(\mathrm{CF} / \mathrm{A}) * \mathrm{D} 3$ & & & $\begin{array}{l}0.5718 \\
(0.411)\end{array}$ & & \\
\hline$(\mathrm{CF} / \mathrm{A})^{*}(1-\mathrm{D} 3)$ & & & $\begin{array}{l}1.9288 \\
(0.04)\end{array}$ & & \\
\hline$(\mathrm{CF} / \mathrm{A}) * \mathrm{D} 1 * \mathrm{D} 3$ & & & & & $\begin{array}{l}0.1766 \\
(0.337)\end{array}$ \\
\hline$(\mathrm{CF} / \mathrm{A}) * \mathrm{D} 1 *(1-\mathrm{D} 3)$ & & & & & $\begin{array}{l}0.8469 \\
(0.015)\end{array}$ \\
\hline$(\mathrm{CF} / \mathrm{A}) *(1-\mathrm{D} 1) * \mathrm{D} 3$ & & & & & $\begin{array}{l}0.6343 \\
(0.033)\end{array}$ \\
\hline$(\mathrm{CF} / \mathrm{A}) *(1-\mathrm{D} 1) *(1-\mathrm{D} 3)$ & & & & & $\begin{array}{l}0.8532 \\
(0.074)\end{array}$ \\
\hline $\mathrm{N}$ & 5472 & 5472 & 5472 & 5472 & 5472 \\
\hline M1 & $\begin{array}{l}-2.666 \\
(0.008)\end{array}$ & $\begin{array}{l}-2.335 \\
(0.020)\end{array}$ & $\begin{array}{l}-2.540 \\
(0.011)\end{array}$ & $\begin{array}{l}-2.728 \\
(0.006)\end{array}$ & $\begin{array}{l}-2.763 \\
(0.006)\end{array}$ \\
\hline M2 & -0.788 & -0.534 & -1.704 & -0.920 & -1.615 \\
\hline
\end{tabular}




$$
\begin{array}{lllll}
(0.431) & (0.593) \quad(0.088) \quad(0.358) \quad(0.106)
\end{array}
$$

$\begin{array}{llllll}\text { Sargan test } & 55.453 & 35.397 & 28.337 & 66.611 & 43.183 \\ & (0.458) & (0.819) & (0.447) & (0.157) & (0.421) \\ \text { Differenced Sargan }^{\mathrm{e}} & 21.66 & 7.63 & 16.89 & 42.31 & 20.47 \\ & {[16]} & {[15]} & {[9]} & {[27]} & {[13]} \\ \text { Critical value Dif. Sargan } & 26.30 & 25.00 & 16.92 & 40.11 & 22.36 \\ & & & & & \\ \text { WALDJS }^{\mathrm{f}} & 9.857 & 11.153 & 11.414 & 21.616 & 14.044 \\ & (0.020) & (0.011) & (0.010) & (0.001) & (0.015) \\ \text { WALDTM }^{\mathrm{g}} & 13.153 & 6.656 & 6.844 & 7.498 & 7.375 \\ & (0.068) & (0.466) & (0.445) & (0.379) & (0.391)\end{array}$

\footnotetext{
All variables are scaled by beginning-of-period total assets, A. Dependent variable is investment, measured as the change in gross fixed assets. Independent variables are sales, S, and cash flow, CF. The dummy variables D1, D2, and D3 refer to group affiliation (1 if affiliated, 0 if not), size ( 1 if small, 0 if large), and age (1 if young, 0 if old), respectively.

b P-values are in parentheses.

c For the equation in first differences, lagged levels are used as instruments. For the equation in levels, first differences are used as instruments. Time dummies are also included as instruments. The exact set of instruments differs per variable and per equation. It is determined by comparing the Sargan test statistics of different possibilities. The exact set of instruments can be obtained on request.

d Equations 4 and 5 are estimated with Moore-Penrose pseudo inverse to evaluate the weighting matrix. The reason is that the total number of instruments in these estimates are relatively large, leading to difficulties in inverting the matrix required to compute the two-step GMM estimator.

e The degrees of freedom for the Differenced Sargan test are in square brackets.

$\mathrm{f}$ WALDJS gives the test statistic for a Wald test of joint significance of the independent variables; $p$-values are in parentheses.

g WALDTM gives the test statistic for a Wald test of the significance of the time dummies (coefficients are not reported); p-values are in parentheses.
} 